\title{
Study on the Open Management Strategy of Yuma Sports Park of Wuhan Business University*
}

\author{
Zhuo Sun \\ College of Physical Education \\ Wuhan Business University \\ Wuhan, China 430056
}

\begin{abstract}
By studying the operation mode of racecourse in other colleges and universities in China, this project mainly combines the professional characteristics of our university to determine the operation mode of open management of Yuma Sports Park. At the same time, it analyzes the important significance of Yuma Sports Park's open management in our university, and puts forward the strategy of open management for Yuma Sports Park in our university by analyzing the factors influencing Yuma Sports Park's open management.
\end{abstract}

Keywords-Yuma Sports Park; open management; strategy

\section{INTRODUCTION}

The Seventh Military World Games will be held in Wuhan in 2019, and it is the largest and highest level comprehensive sports event ever held in Wuhan. To hold the competition better, Wuhan has invested RMB 10 billion to newly build the athletes' village, media center and related stadiums. Some of stadiums are located in six universities including Wuhan Business University, Jianghan University, etc. The Wuhan Municipal Government determines to place the venue of equestrian event in the modern pentathlon in Wuhan Business University to better promote the development of horse racing and equestrian professional. In order to better host the competition, the municipal government plans to invest RMB 119,461 million to acquire a new land for building the Yuma Sports Park with the theme of equestrian stadium in Wuhan Business University.

The stadiums in colleges and universities will not only be used by the Seventh Military World Games, but also serve teachers and students in the university and the surrounding residents after the game. Yuma Sports Park of Wuhan Business University is built with huge investment, and it is also the first equestrian stadium in central China to host the international-level equestrian event. The Wuhan Municipal Government has announced that after the end of the games, apart from ensuring the use of Wuhan Business University's teaching and training, Yuma Sports Park will also be open to Wuhan residents to meet their needs of fitness. This paper analyzes the necessity and feasibility of the management and development of Yuma Sports Park in our university and puts forward some suggestions, which will provide the theoretical basis for the open management and development of the Park

*University-level Scientific Research Projects of Wuhan Business University; Project No.: 2018KY003. after the Seventh Military World Games.

\section{NECESSITY OF MANAGEMENT AND DEVELOPMENT OF YUMA SPORTS PARK}

\section{A. Solving the Problem of Idle Stadiums After Major Competitions}

In recent years, there are many large-scale world-class events held in China. Many large-scale stadiums have been built to host these events. Many stadiums are idle after the event. Due to the high maintenance cost, many stadiums will be shut down immediately after the event, which is a huge waste of social resources. For example, the racecourse stadium of National Games of the People's Republic of China in Nanjing is overgrown with weeds, and has become a large parking lot. Therefore, over the years, the research on the post-event utilization of large stadium has become a hot topic in China's sports circles. Wuhan Business University has an equestrian college, which is also a very important reason for the Wuhan Municipal Government to decide to build the stadium there. We should make good use of human resources to manage and develop Yuma Sports Park to provide a good example for the future use of horse racing and equestrian stadium of major events.

\section{B. Creating and Providing Professional Training Posts, Enhancing Students' Practical Skills and Promoting Personnel Training}

Wuhan Business University first recruited college student jockeys in China in 2008. At present, it has trained more than 1,000 talents for the horse industry in China. Wuhan Business University has clearly put forward to build itself into an applied university. Horse racing and equestrianism is a brand specialty of Wuhan Business University, and the university leaders have repeatedly proposed to strive to make horse racing and equestrianism become a first-class discipline. In order to improve the quality of training talents for horse racing and equestrian majors, it is very important to improve students' practical ability and create more practical training opportunities for them. The open operation and management of Yuma Sports Park will inject new impetus and add new vitality into the development of the university. The open management of the stadium will allow more course teaching to directly connect with the market, make course 
teaching out of classroom and permit the students to improve their practical skills in the operation of market. During the four years of university study, students are integrated into various positions in the Yuma Sports Park, so that they work independently after they graduate.

\section{Responding to the Government's Call to Open College Stadiums to Meet Citizens' Demand for Fitness}

On October 20, 2014, the State Council issued "Several Opinions on Accelerating the Development of Sports Industry and Promoting Sports Consumption" and made some deployments. It pointed that we should actively expand the supply of sports products and services, promote the sports industry to become an important force for economic transformation and upgrading, advance the all-round development of mass sports and competitive sports, and accelerate the building of China into a sports power, to constantly meet the people's growing demand for sports. Meanwhile, the Fifth Plenary Session of the 18th CPC Central Committee first proposed to promote the construction of a healthy China, and the "healthy China" has become a national strategy. General Secretary Xi Jinping has repeatedly put forward that we should vigorously develop sports and form a healthy lifestyle.

In order to better solve the problem of fewer fitness stadiums for the masses, the Ministry of Education and the General Administration of Sport of China jointly issued the Opinions on Promoting the Opening of University Stadium to the Society, which clarified the scope and time of the opening of university stadium, that is to say, university should open the stadium to students in after-class time and holiday. Public universities should actively create conditions for opening the stadium to the society.

From the above two policies, Yuma Sports Park in our university is open to the public after its completion in line with national policies and regulations, which can promote sports consumption and boost the development of the equestrian industry in Wuhan.

\section{Keeping the Daily Expenses of Horses and Stadiums Maintenance and Reducing the Burden of the University by Operating and Developing Yuma Sports Park}

Yuma Sports Park covers an area of more than 200 acres. Forty horses are planned to be fed in the Park to ensure daily teaching and training after the end of the Seventh Military World Games in 2019. A horse costs at least RMB 2,000 a month for breeding. To manage forty horses, at least 10 fulltime employees are needed for daily horse training. Coupled with personnel wage for greening, cleaning and security, and daily maintenance costs, the Park's daily expenditures are high. The normal operation of the Park in the future will give a heavy economic burden on our university, and it is unrealistic to entirely rely on financial appropriations. Therefore, we should make the Park open to the public, provide services to the public to create benefits, and strive to make the Park balanced and reduce the financial burden of the university.

\section{PROBLEMS IN OPEN MANAGEMENT OF YUMA SPORTS PARK}

\section{A. The Contradiction Between Opening and Teaching}

After the opening of the Yuma Sports Park, there certainly will be some conflicts with the teaching. For example, visitors will affect the teachers and students in class, and members who come for leisure and riding may use horses and venue simultaneously. University is a place for teaching and educating, so the primary task of teaching stadiums in colleges and universities is to ensure teaching. The university must deal with the contradiction between the opening of Yuma Sports Park and teaching activity. The normal teaching cannot be affected, and all market-oriented behaviors are best done outside normal teaching hours. Yuma Sports Park covers a large area, and reasonable planning arrangement can handle this contradiction better.

\section{B. Lack of High-end Talents for Stable Management and Club Operation and Management}

The biggest difference between Yuma Sports Park and other stadiums is that there are horses in the Park, so the management of the stadium is difficult. The operation of the racecourse must focus on horses, and the personnel in the racecourse must know about horses and understand their habits, otherwise, it is difficult to manage Yuma Sports Park. Besides, horses in the Yuma Sports Park are warm-blood horses purchased from foreign countries at a high price in the future. The horses are general about 1.8 meter in shoulder height and more than $500 \mathrm{~kg}$ in weight with large size. Horses for teaching in our university are both Mongolian horses and Xinjiang horses. In the future, the breeding and management of warm-blood horses and even their daily training are different, and the requirements will be higher. At present, our university has few talents in this field, and the current teaching team cannot undertake the daily maintenance of so many horses. Horses need proper exercise and scientific feeding every day, and normal opening cannot be guaranteed without good daily care.

\section{Security Risks After Opening to the Society}

Human beings are very weak compared with the horses. Sometimes horses' instinctive behaviors, such as collisions, biting and so on, are easy to hurt people. Equestrian sports are also high-risk events, especially when people jump obstacles on horseback, they may fall down from the horses and get hurt. After the Yuma Sports Park is open to the public, there are more tourists coming to the park, so the probability of security incidents is also increasing. It can be expected that there will be more children coming to play in the future, and they will be very interested in horses. If the management is not strict, children will be accidentally bitten by horses when they are close to the horses, and tourists will fall down from the horse and get hurt. Yuma Sports Park belongs to the university, and the university will inevitably assume certain responsibilities in case of accidents. Therefore, this safety hazard is also a major problem affecting the opening of Yuma Sports Park. 


\section{The School Has No Relevant Policy Support, and} Teachers' Enthusiasm for Participating in Operations Is Not High

The teams of teachers in horse racing teaching and research office have different research directions for horse racing and equestrian, including club operation management, veterinary, stable management, competition, equestrian skill, training and other directions. If these teachers can participate in the operation and opening of Yuma Sports Park, it will promote the Park's rapid development operation efficiency. However, the main duties of college teachers are to conduct teaching and research activities. At present, there is no relevant policy to encourage teachers to start their own businesses and take part-time jobs. Moreover, because of the eight provisions of central government, colleges and universities cannot issue any subsidies to the in-service teachers at present. Many public institutions share fruits of labor equally and there is no difference between the good or bad results, which makes teachers' enthusiasm for participating in entrepreneurship not high.

\section{COUNTERMEASURES OF OPEN MANAGEMENT OF YUMA SPORTS PARK}

\section{A. Operating and Managing This Park Through Professional Management Team or Sports Company by Means of Bidding}

Due to the horses existing in Yuma Sports Park, the professionalization degree of management becomes high, especially the management of warm-blood horse should be operated by professional. Although the university has professional team of teachers, their main tasks are to teach students and make research activities, therefore, they cannot manage the park with full-time job. So, the university should change the ideas and recruit professional management team or horse companies to manage this park. The university signs an agreement with them, and even does not charge rent for them in the first few years. However, the third company should make promise that they will manage the horses well and burden all the expenditures of Yuma Sports Park, which not only can reduce the economical burden, but also recruit high-level horse training team to train the horses and guarantee the teaching activities. These companies have a team of coaches and rich horse marking management experience. Therefore, this park is better to be managed by private enterprises rather than the university.

\section{B. Formulating Relevant Policies and Encouraging Professional Teachers to Participate in Operation and Management}

If the team of teachers of horse competition teaching and research office in our university could participate in the management and operation of Yuma Sports Park, it will greatly improve the management and operation efficiency of this park. However, from the conversation with related teachers, the author learns that the teachers of horse competition in our university do not have high enthusiasm to participate in the future open management of Yuma Sports Park. For example, a horse needs to be ridden to keep health in every day, and it also requires high scientific feeding and training to keep in good condition. So it requires the employee to work all the year round, and even they do not have holidays and festivals. However, under the current policies, this kind of action does not have any reward and the university cannot pay any subsidy for teachers in this job. The work is beyond the teaching work of teachers, so the teachers do not have high enthusiasm to participate in it. Therefore, our university formulates related policies to calculate the workload of teachers who participate in the management of Yuma Sports Park, pay them reasonable remuneration and arouse the enthusiasm of teachers.

\section{Strengthening the Safety Management for Yuma Sports Park}

The growing tourist amount increases the potential risks. Therefore, the relevant management personnel of Yuma Sports Park should have high predictability, prevent and deal with possible potential risks in time, and reduce the risks in the opening process of the stadium. For those horses which are unstable and easy to harm people, there should be conspicuous safety precautions to avoid the tourists from being bitten when touching and taking photos for those horses. The park should formulate detailed and thoughtful Yuma Sports Park Safety Precautions and Safety Regulations for Member's Riding and other rules and regulations, and persuade the tourists who enter the park and deal with membership to ride the horse to obey the rules and regulations.

Equestrianism is a high-risk sport, and managers must develop a set of related sports insurance system to transfer the risks of Yuma Sports Park through cooperation with insurance companies. Buying services at an insurance company can also include part of insurance premium in the site fees. Only by establishing a sound insurance system can the school make sure that the Yuma Sports Park will be open to the public.

\section{Building Brand Competition and Expanding Popularity of Yuma Sports Park in China}

A global city with profound humanistic connotations should have its own iconic sports events, such as Aachen's equestrian festival and Melbourne's horse racing festival. These activities attract hundreds of thousands of people from around the world to watch the great competition and the events have become an annual festival for local people.

As a megacity in central China, Wuhan has put forward the slogan to revitalize Wuhan City in recent years. After the completion of Yuma Sports Park, it will become the only place to undertake international equestrian events in central China. This park will take advantage of the professional advantages of the business school to create another top-level event for Chinese equestrianism as the events in the Beijing's Bird's Nest, and transform it into a national culture event. The event will radiate its influence to the surrounding areas to promote the development of urban functions and enrich the lives of the people. 


\section{E. Formulating Reasonable Charge Standard}

Colleges and universities are places to teach and educate people and they should not take making money as the first purpose. However, if Yuma Sports Park is contracted to operate privately, the primary consideration is to make money and only the reasonable charge standard can attract more people to increase consumption.

The charge standard of colleges and universities' stadium should be priced in strict accordance with the relevant provisions of the local price department. At the same time, a reasonable price should be set according to the charge standard of other equestrian clubs in Wuhan. Within the limits of the laws and regulations, reasonable charge standard should be set for different consumer groups. For the college students in our university, there should be the most preferential charge policy to meet the demands of their fitness exercises; for teaching and administrative staff, there will be certain preferential policy when they present related certificates; for the social persons, they can be charged according to the commercial standard. Some correlative charges, such as membership fee, fosterage fee and teaching fee, should be open and transparent. At the same time, Yuma Sports Park can adopt different charge standards according to various time. In particular, the charge standard in daily school session, winter and summer vacation and holidays and festivals should be different.

\section{CONCLUSION}

1. Yuma Sports Park is the only place to undertake international equestrian events in central China. Due to the participation of animals in the event, its operating management differs from other stadiums.

2. The openness of Yuma Sports Park towards society is conducive to reducing university's financial burden and provides theoretical foundation for the post-games use of great equestrianism stadium, at the same time, it also contributes to cultivating more high-quality applied talents.

3. The first condition of openness of Yuma Sports Park towards society is to formulate preferential policy, motivate people's enthusiasm and introduce high-level operation and stable management team.

4. This park will become a scenic spot of leisure and entertainment for people in Wuhan only by strengthening the safety management, formulating reasonable charge standard, and setting various playing service programs.

\section{REFERENCES}

[1] Cong Huping. Sports [M]. Beijing. Higher Education Press, 2004. 8.

[2] Sun Zhuo, Zhang Teng, Zhang Shuang. Research on the Management and Development of the Training Racecourse of Wuhan Business University [J] The Guide of Science \& Education, 2013, (4): 34-35.

[3] Sun Zhuo, Zhang Teng. The Research on the Current Situation of Management and the Development Countermeasures of Equestrian Club in Our Country [J] Journal of Wuhan Commercial Service College, 2013, (1): 11-13.

[4] Zhong Tianlang. Sports Management--Theory and Practice [M]. Shanghai: Fudan University Press, 2004. 